\title{
Interest Rate Risk and the Stock Prices of Financial Institutions
}

\author{
G. J. Santoni
}

$\mathbf{M}$ movements on the portfolos of financial institur movements on the portfolios of financial institutions typically conclude that the relatively high and volatile interest rates of the past 15 years have placed many of these institutions in jeopardy of failing. The consensus of many of these discussions is that institutions with "unbalanced" portfolios and low capital are particvlarly susceptible to interest rate movements. ${ }^{~}$

The purpose of this paper is to analyze the effect of interest rate changes on the relative value of financial institutions. ${ }^{2}$ This issue is important not only to the owners, managers and emplovees of fnancial institutions but to monetary policymakers as well. Monetary policy actions affect interest rates. If the viability of financial institutions is particularly sensitive to interest rate changes, monetary policymakers will want to take this effect into account.

G. J. Santoni is a senior economist at the Federal Reserve Bank of St. Louis. Thomas A. Pollmann provided research assistance.

${ }^{\top}$ See, for example, Maisel and Jacobson (1978), p. 688; Kaufman (1984); Bierwag, Kaufman, and Toevs (1983); Hopewell and Kaufman (1973); Flannery (1981); and Samuelson (1945).

"More correctly, it is unexpected changes in the interest rate that affect relative values. Any future change that is expected is reflected in current prices. Long-term interest rates are important determinants of stock prices, and changes in these interest rates can be characterized as unexpected (see footnote 15).

\section{FINANCIAL INSTITUTIONS AND INTERMEDIATION}

Financial institutions intermediate many transactions between bortowers and lenders. In doing so, banks and savings and loans do not act merely as credit brokers, negotiating credit transactions between borrowers and lenders. Rather, they borrow directly from some individuals and lend directly to others. These transactions make up the portfolio of the financial firm. In large part, the market value of the firm is determined by the net present value of its portfolio of assets and liabilities. Changes in the interest rate affect the firm's market value because they influence the present value of the assets and liabilities in the firm's portfolio.

\section{INTEREST RATE CHANGES AND THE RELATIVE PRICE OF FINANGIAL INSTRUMENTS}

Since the interest rate is the price of the earlier avalability of dollars, a change in the interest rate means that this price has changed. ${ }^{3}$ For example, if the

\footnotetext{
${ }^{3}$ Since this paper is mainly concerned with changes in the whole complex of interest rates (i.e., changes that leave the term structure unattered), "the" interest rate is used as a shorthand method of referting to the complex of interest rates.
} 


\section{Table 1}

\section{Present Values and Interest Rate Changes}

Dare or payment

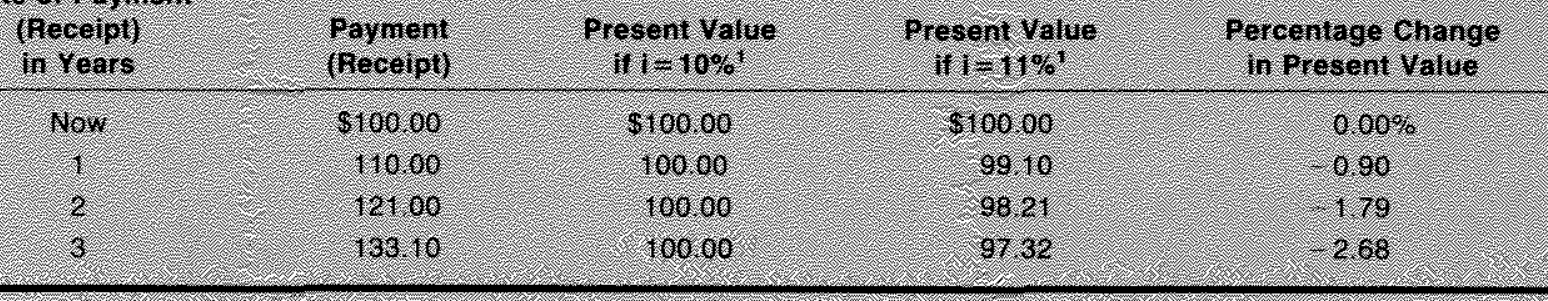

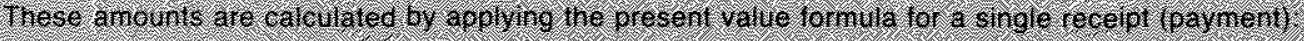

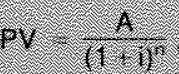
Where pl presenvalue

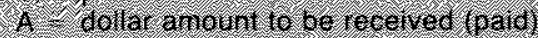
1. 1 inarest rate in tecinat brim

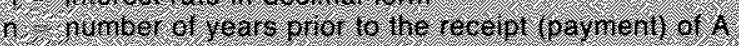

interest rate rises from a level of 10 percent to 12 per. cent, the price (or valuel of present dollars rises in tems of future dollars. Before the change in the interest rate, borrowing a dollar today necessarily meant giving up 1.10 dollars one year from now or 1.21 dollars two years from now, etc. After the increase in the interest rate, borrowing a dollar today requires the sacrifice of 1.12 dollars one year from now or 1.25 dollars two years from now, etc.

Since financial instruments represent claims to dollars at different points in the future, changes in the interest rate affect the relative values of financial assets and liabilities. A rise in the interest rate has two important effects on financial claims. First, it reduces the present value of all such instruments in terms of present dollars. Second, and equally important, the present values of various instruments will change in terms of each other; the prices of claims to dollars in the more distant future will fall relative to the prices of claims to dollars in the near future.

Table 1 presents an example that illustrates the effect of an interest rate change on the present values of four different financial instruments. The instruments are similar in that each promises a single future dollar receipt (payment) of a given amount; they differ in both the amount to be received (paid) and timing of the receipt (payment). The first column of the table indicates when each receipt will occur. The second column shows the amount to be received. Columns three and four give the present values of the various instruments at two different interest rates. The last column shows the percentage change in present value that occurs when the interest rate rises.

The example is constructed so that the present value of each instrument is $\$ 100$ at an interest rate of 10 percent. Because each is worth $\$ 100$ at this interest rate, each will exchange one-for-one in the market. An increase in the interest rate, however, will completely alter this set of relative prices.

The increase in the interest rate from 10 percent to 11 percent causes the present value of each instrument that promises future dollars to fall. Those that represent earlier claims to dollars, however, become relatively more valuable compared with those that promise dollars in the more distant future as indicated by the smaller percentage reductions in the present values of these instruments

\section{Interest Elasticity: A Fundamental Measure of Interest Rate Risk}

Discussions of the impact of an interest rate change on the prices of financial assets have a long history in economic literature and are typically referred to as the "elasticity of capital value with respect to the interest rate."

This "elasticity" is simply the percentage change in the present value of an asset (liability) divided by the percentage change in the interest rate. The number that results approximates the percentage change in

\footnotetext{
${ }^{4}$ See Hicks (1939), pp. 184-88, and, more recently, Alchian (1955)
} 


\section{Table 2}

\section{Interest Rate Elasticities Calculated from Table 1}

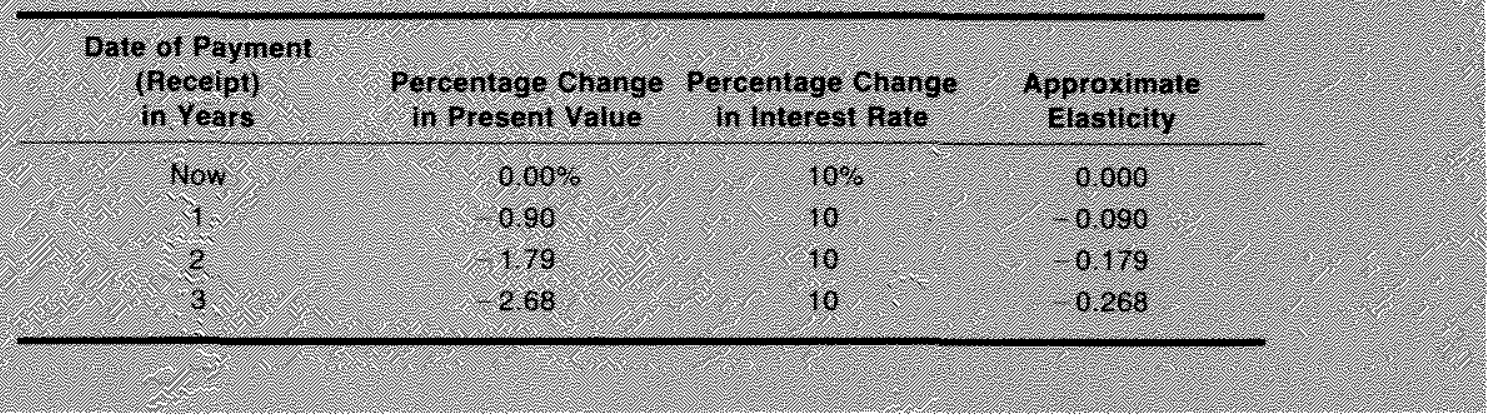

the present value that will occur for a 1 percent change in the interest rate.

Interest elasticity measures the sensitivity of the present value of an asset (liability) to interest rate changes. The larger the absolute value of the elasticity, the greater is the percentage change in present value for a given percentage change in the interest rate and, consequently, the more sensitive is the value of the asset to interest rate changes. ${ }^{6}$

Table 2 uses the data in table 1 to calculate the approximate interest elasticities of the various instruments. The larger elasticity (in absolute value) for the more distant receipts indicates that their present values are more sensitive to interest rate changes.

The examples in tables 1 and 2 consider only assets that consist of single receipts at different dates in the future. The same procedure, however, works for assets that yield any conceivable stream of future receipts. All that is required to calculate an interest elasticity is the ability to calculate present values at different interest rates. This is comparatively easy, provided that present value tables and a hand calculator are readily available. For example, table 3 shows how to use the present value table (shown at the bottom of table 3 ) to compute the interest elasticity of an asset yielding a varying stream of receipts (one of which is negative) over a five-year period when the interest rate is around 10 percent. The elasticity is -.275 , indicating that a 1

${ }^{5}$ It is an approximation because the calculation holds only for small changes in the interest rate.

since present values and interest rates are inversely related, the elasticity measure will always be negative. percent increase in the interest rate reduces the present value of the asset by slightly more than 27 percent.

\section{Duration: Another Measure of Interest Rate Risk}

More recently, the concept of interest rate elasticity has been applied in the area of financial management where it has appeared in the guise of the "duration of the financial portfolio and interest rate risk. "Usually, different names are used to identify different things. In this case however, there seems to be a distinction with no real difference.

Like elasticity, duration is a number that ranks the interest rate sensitivity of various assets. Unlike elasticity, however, which is a "pure" number (i.e., is not dimensioned in any particular unit), duration is expressed in units of time. The duration of an asset is the "average" length of time that receipts are deferred from the present. In calculating the average, the time period that each receipt is deferted is weighted by the discounted value of the receipt. ${ }^{8}$ As the duration of an asset increases las the average length of time one must wait for payment risesi, the interest rate sensitivity of the asset also increases.

Interest rate elasticity and duration are closely related concepts. In fact, for given interest rates; the duration of any asset is simply its interest elasticity

\footnotetext{
7 "Duration has now emerged as an mportant tool for measuring and managing interest rate risk." Bierwag, Kauman, and Toevs, p. 15. See, as well, Hopewell and Kauman.

8Hicks, p. 186.
} 


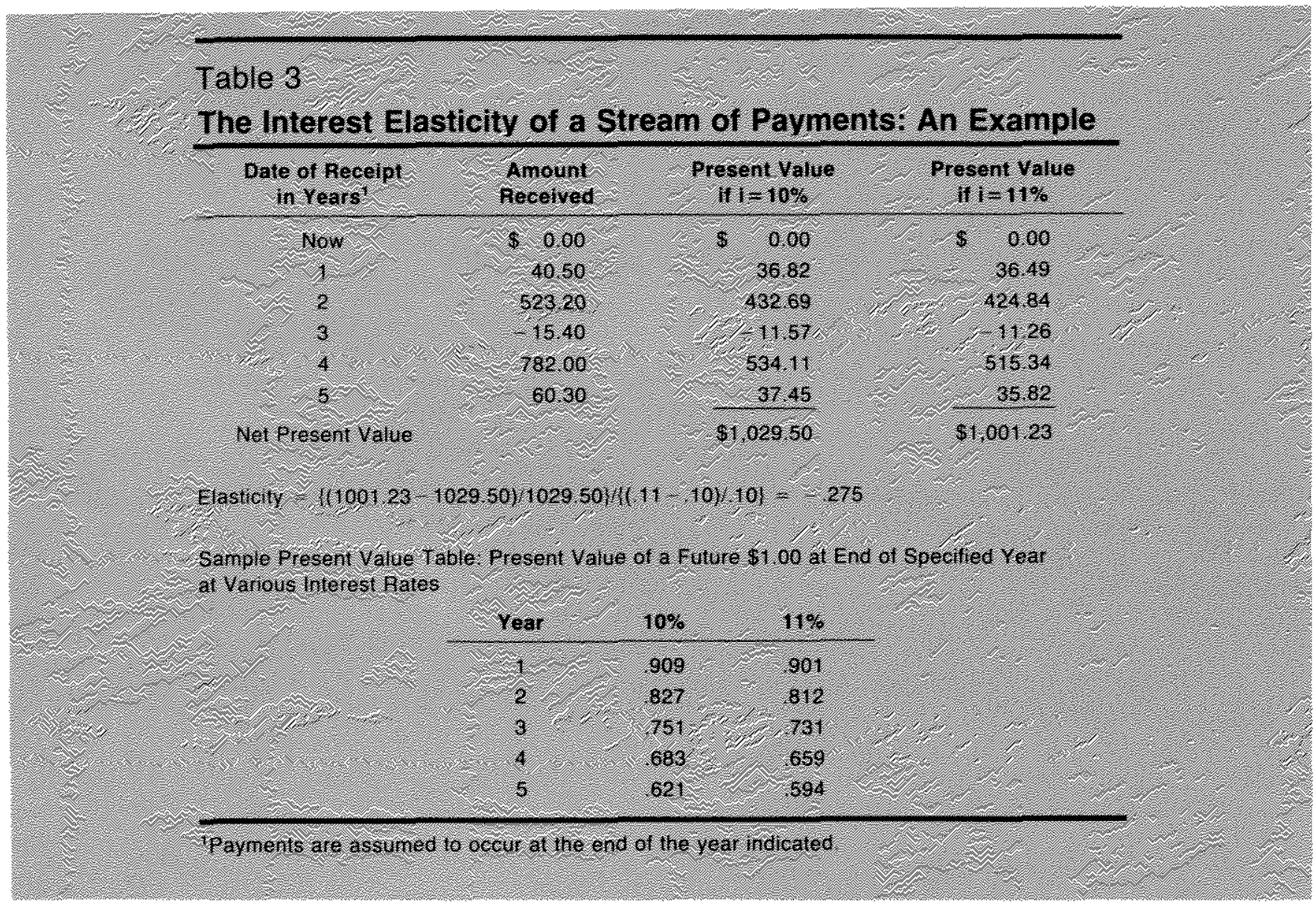

multiplied by the factor $-(1+\mathrm{i}) / \mathrm{i}^{9}$ Consequently, the duration and interest rate elasticity produce identical

9 The elasticities of the present values of various types of assets (liabilities) with respect to the interest rate are given by:

$A$. In the case of a single receipt (payment) of A dollars $n$ years in the future, the present value is:

$P=\frac{A n}{(1+i)^{n}}$ and

$\frac{d P}{d i} \frac{i}{P}=-n \frac{i}{(1+i)} . \quad$ Duration $=\frac{d P}{d i} \frac{1}{P}\left[-\frac{(1+i)}{i}\right]=n$.

In this case, duration is equal to $n$, the number of years one must wait before receipt (payment) of $A$.

B. In the case of a stream of receipts (payments) of various expected amounts, $A_{1}$, at the end of each year for $n$ years, the present value is:

$$
\begin{aligned}
& P=\sum_{t=1}^{n} \frac{A_{t}}{(1+i)^{t}} \\
& \frac{d P}{d t} \frac{i}{P}=-\left[\sum_{t=1}^{n} \frac{t A_{i}}{(1+i)^{t}} / \sum_{t=1}^{n} \frac{A_{t}}{(1+i)^{t}}\right] \frac{i}{(t+i)} \\
& \text { and Duration }=\frac{d P}{d i} \frac{i}{P}\left[-\frac{(1+i)}{i}\right]
\end{aligned}
$$

rankings of assets and liabilities in terms of their interest rate sensitivity or risk.

If the interest rate elasticity of an asset is known (and it is always relatively simple to estimate), its duration can be immediately obtained. For the examples used in table 1, the approximate durations of the various assets are $0.00,0.99,1.97$ and 2.95 years, respectively. The

The duration of this instrument is measured by the term in brackets, i.e., the "average length of time for which the various payments are deferred from the present, when the times of deferment are weighted by the discounted values of the payments (emphasis in the original)." Hicks, p. 186.

C. In the case of a perpetual stream of receipts (payments) of equal annual amounts, $A$, present value is:

$P=\frac{A}{i}$ and

$\frac{d P}{d i} \frac{i}{P}=-\frac{(1+i)}{i} \frac{i}{(1+i)}=-1$ or $\frac{(1+i)}{i}=\frac{d P}{d i} \frac{i}{P}\left[-\frac{(1+i)}{i}\right]$.

The duration of this instrument is $(1+i) /$ and the percentage change in its price is equal to the percentage change in the interest rate. Note that in each of the three cases duration is always equal to interest rate elasticity, $\frac{d P}{d i} \frac{i}{P}$, multiplied by $-(1+i) / i$. 
approximate duration of the asset shown in table 3 is 3.02 years. $^{10}$

\section{The Effect of Interest Rate Changes on "Unbalanced" Portfolios}

Changes in the rate of interest generally will change the present value of a firm's assets relative to its liabilities. When this occurs, the market value of the firm will change. If the firm's shares are publicly traded, the change in the firm's value will be reflected by a change in the price of its shares. Thus, the market value of a firm is sensitive to interest rate changes, and this sensitivity generally will differ across firms.

As in the case of particular assets on liabilities, the sensitivity of the value of the firm to interest rate changes can be measured by the elasticity of the present (market) value of the firm with respect to the interest rate. ${ }^{11}$ Unlike the case for a particular asset or liability, however, the interest rate elasticity of the present value of the firm may be positive, negative or equal to zero. If positive, the market value of the firm will lise as interest fates rise and fall as interest rates fall. If negative, the reverse is true; if zero, the net present value of the firm is unaffected by interest rate changes.

Table 4 presents an example of each possibility. In panel $A$, the interest elasticity of net present value is negative. Interest elasticity is positive in panel $B$ and equal to zero in panel $C$. The example is constructed so that the net present values are identical when the interest rate is 10 percent. In addition, the construction

to These are approximate durations because the elasticities computed in the tables are estimates of the true elasticity (see footnote 6 ). The exact durations are $0.00,1.00,2.00,3.00$ and 3.10 years (see footnote 9).

${ }^{11}$ Let $A_{t}$ and $C_{t}$ be, respectively, the dollar value of the firm's receipts and the dollar value of its payments in pertod $t$. If the life of the firm is $n$ years, the market value of the firm in period $t, M_{t}$ is:

$$
\begin{aligned}
& M_{t}=\sum_{t=1}^{n} \frac{A_{t}}{(1+i)^{t}}-\sum_{t=1}^{n} \frac{C_{t}}{(1+i)^{2}} \\
& \frac{d M_{t}}{d i} \frac{i}{M_{t}}=-\frac{i}{(1+i)}\left[\frac{\sum \frac{t \cdot A_{t}}{(1+i)^{1}}-\sum \frac{t \cdot C_{t}}{(1+i)^{t}}}{\sum \frac{A_{t}}{(1+i)^{t}}-\sum \frac{C_{t}}{(i+i)^{7}}}\right]
\end{aligned}
$$

As long as the market value of the firm is positive, i.e., the denominator exceeds zero,

$$
\begin{aligned}
& \frac{\mathrm{dM}_{\mathrm{i}}}{\mathrm{di}} \frac{\mathrm{i}}{\mathrm{M}_{\mathrm{t}}} \geq 0 \text { as }\left[\Sigma \frac{\mathrm{t} \cdot \mathrm{A}_{t}}{(1+\mathrm{i})^{\mathrm{I}}}-\Sigma \frac{\mathrm{t} \cdot \mathrm{C}_{1}}{(1+i)^{\mathrm{i}}}\right] \leq 0 \\
& \text { See Samuelson, p. } 19
\end{aligned}
$$

is such that the ratio of assets to liabilities (leverage) is initially the same for each firm.

An increase in the interest rate from 10 percent to 11 percent causes the net present value of the firm in panel $A$ to fall by $\$ 3.62$, rise by $\$ 1.19$ in panel $B$ and remain unchanged in panel $C$. The explanation for this differential effect is that the increase in the interest rate lowers the present value of firm $A$ 's assets relative to the present value of its liabilities, causing its net worth to fall. The reverse is true for firm $B$, while for firm $C$ the present values of assets and liabilities fall proportionally, leaving its net worth unchanged.

\section{DURATION: SOME COUNTERINTUITIVE ANOMALIES}

Since the duration of an asset or liability is in terms of units of time, it may appear to be a more intutively appealing measure of interest rate sensitivity than elasticity, which is a pure number. However, duration has some counterintuitive qualities that emerge when it is applied directly to the net flow of receipts generated by the firm (i.e, when the firm is treated as a single asset).

\section{There Is Less in Duration Than Meets the Eye}

While duration presumably measures the average length of time that receipts and payments are deferred from the present, the measurement can produce some unusual results. This is apparent in panel A where the duration of the portfolio is approximately 8.76 years, while the durations of the asset and liability are only 5.0 and 1.0 years, respectively. Intuitively, it would seem that the duration of the portfolio should be no more than 5.0 years. The asset will mature after five years, so a measured duration of 8.76 years is somewhat unusual in terms of the way averages (even weighted averages) are normally computed. This odd result occurs because duration employs an unusual method in weighting the streams of receipts and payments isee footnotes 9 and 11 ).

As a further illustration, notice that the duration of the portfolio in panel $B$ is negative. In a mechanical sense, this result is not surprising. Duration is always equal to interest elasticity multiplied by $-(1+\mathbf{i}) / \mathrm{i}$. For the firm in panel $\mathbf{B}$, interest elasticity is positive and $-(1+i) / i$ is negative. So duration, the product of the positive and negative numbers, is negative. However, a portfolio with a negative average life is surely counterintuitive. This result indicates that duration is more appropriately thought of as a proxy for the interest rate 


\section{Table 4 \\ Net Present Values and Interest Rate Changes: Elasticity and Duration Measures}

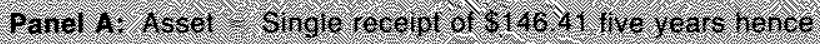

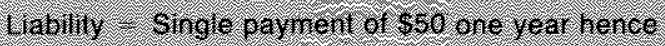

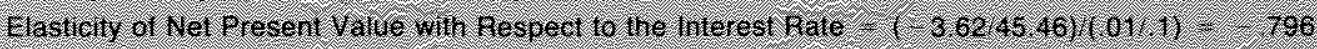

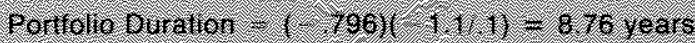

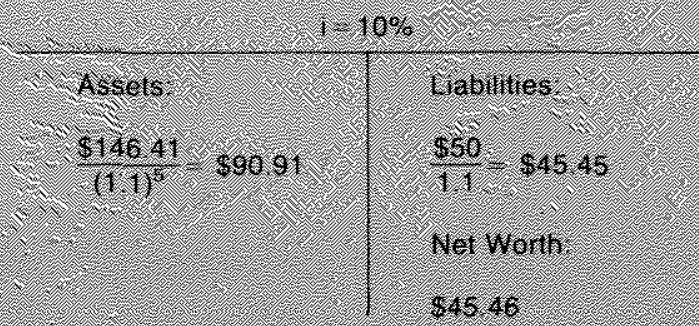

(1)

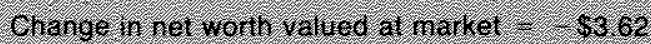

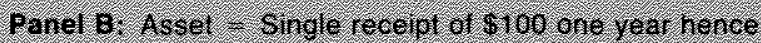
Lrabilif single payment of $\$ 30.20$ f ve years herce

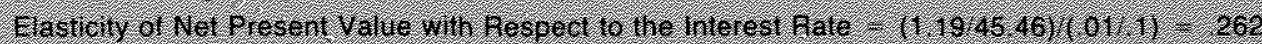

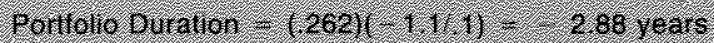

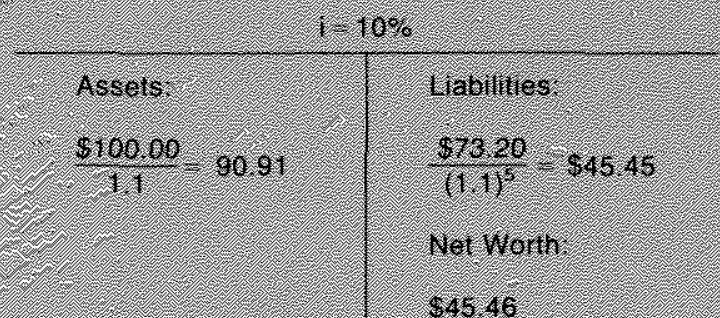

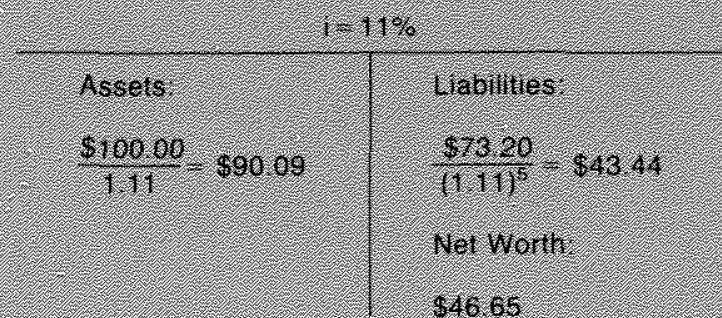

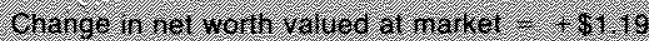

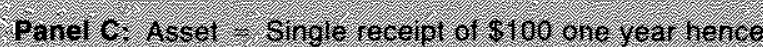

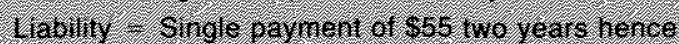

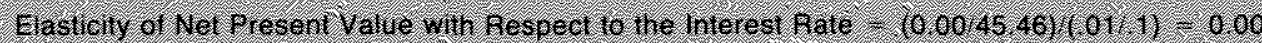

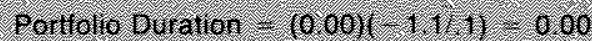

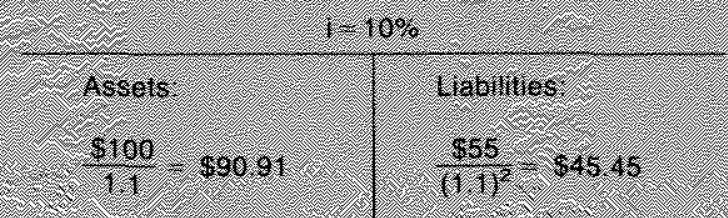

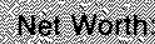

84656

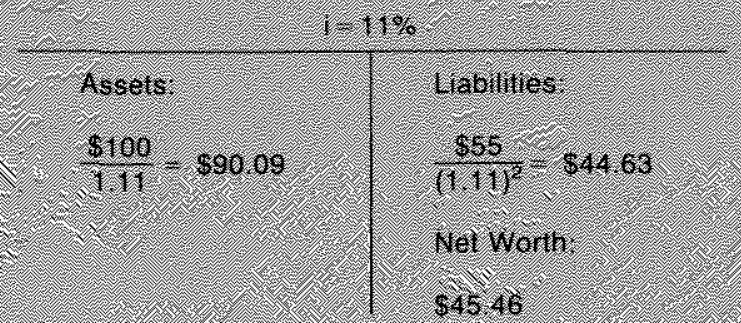

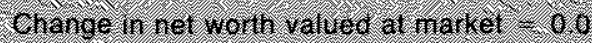


elasticity of the portfolio rather than an indicator of the portfolio's average life.

Thus, at best, duration produces a consistent ranking of assets, liabilities and portfolios in terms of interest rate risk. The ranking is identical to the one that would be obtained by calculating interest rate elasticities. Calculating duration, however, requires an extra computational step and produces a result that reveals very little intuitive information about the average life of the portfolio.

\section{Leverage Affects Portfolio Duration}

An increase in the firm's leverage lan increase in liabilities relative to assets affects the duration of the portfolio, Again, consider panel A of table 4. Suppose that the present values of these particular assets and liabilities were increased by equal amounts so that the firm's net worth remained constant. This increase in the leverage of the firm would also increase the interest elasticity of the portfolio. Since duration is simply the interest elasticity multiplied by $-1+i / / 1$ and, in this case, interest elasticity is negative, the duration of the portfolio will increase even though the average lives of the assets and liabilities were not changed.

\section{Matching Asset/Liability Duration Does Not Eliminate Interest Rate Risk}

Matching asset and liability durations will not insulate the net worth of the firm (valued at market) against interest rate changes. This is particularly apparent in panel $\mathrm{C}$ of table 4. The duration of the firm's asset is one year, while the duration of its liability is two years. Although the firm has a mismatch of asset/liability durations, a change in the interest rate leaves its net present value unaffected.

Insulating the firm against changes in the interest rate requires that the interest elasticity of the portfolio be zero. If the firm's net worth is positive, as must be the case for any viable firm, achieving this result requires that the duration of the firm's liabilities must exceed the duration of its assets. That is, the weighted average length of time for which payments are deferred from the present must exceed the weighted average length of time for which receipts are deferred from the present. $^{12}$

\footnotetext{
12 The above example considers only a single receipt and pay. ment, only a single interest rate, and only one type of asset and liability. The real wonld, of course, is considerably more complicated and, hence, the example used here may appear to be
}

\section{MNTEREST PATR RISK AND FINANCLAL INSTTITITONS}

There is reason to believe that financial firms are best characterized by the firm shown in panel $A$ of table 4 . Notice that in examples $B$ and $C$, the firm's asset matures in one year, while its liabilities extend beyond one year. Once the asset matures, the net present value of the firm is negative land will continue negative throughout its remaining life) uniess the owners reinvest the proceeds of the matured asset.

What are the incentives for the owners to reinvest? If the firm is a corporation and, hence, creditors have no claim on the personal assets of the owners, there is relatively little incentive. The wealth of the owners will be greater if they simply take the proceeds of the matured asset (\$100) as a dividend and declare the firm banktupt. Their wealth will rise by the present value of the liabilities. The incentive to behave in this fashion is greater the larger the liabilities are relative to assets, that is, the greater the firm's leverage.

Financial institutions tend to be highly levered ${ }^{13}$ On average, net worth represents about 5 percent of total assets for these firms. Under these conditions, it is unlikely that financial institutions could attract many depositors if they maintained maturity structures of assets and liabilities similar to those shown in panels B and $\mathrm{C}$. Public trust makes up much of the capital of financial institutions, both literally and figuratively. These institutions provide assurance against the kind of behaviof discussed above by maintaining asset/ liability maturity structures similar to that shown in panel $A$ rather than those shown in panels $B$ and $C$.

This implies that the interest elasticity of the present value of financial institutions will be negative. Positive changes in the interest rate will be associated with reductions in their market values, while negative changes in the interest rate will be associated with increases in their market values. Moreover, the absolute value of the interest rate elasticity should be larger for savings and loan associations than for banks, because they lend on a much longer-term basis than do

unrealistic. However, the same results would be obtained if a more realistic example were employed; all that would be gained by more realism is more complexity.

${ }^{13}$ For example, the ratio of capital to total assets averaged 042 for the 35 banks listed in Salomon Brothers (1983), p. 54, over the most recent five year period. The ratio for all savings and loans is .053 over the same period (Savings and Loan Sourcebook, various years). in contrast, the ratio of capital to total assets for all manufacturing firms averaged .500 over the same period 
banks while both borrow on a short-term basis. ${ }^{14}$

The highly levered portfolios of all financial institutions, as well as the maturity structures of savings and loan portfolios, suggest that the share prices of financial institutions will not only decline, but decline relative to the share prices of other firms when the interest rate rises and, conversely, when the interest rate falls. Because of this, the stock prices of financial institutions should exhibit greater variation around their mean levels than firms that are less highly levered and that maintain more balanced portfolios.

\section{SOME ESTIMATES OF INTEREST RATU EHASTICITIRS}

The above discussion implies that, other things equal, the owners of financial institutions accept more interest rate risk than the owners of nonfinancial firms. To what extent does an analysis of share prices for publicly traded fims support this implication?

To investigate this issue, quarterly data on the percentage change in various indexes of share prices were regressed on the percentage change in the corporate Aaa bond wate over the period from 1961 to 1983 to produce estimates of the interest rate elasticities confronting different types of firms ${ }^{1.5}$ The share price indexes used are the Standard and Poor's indexes of share prices of 400 industrial companies, banks outside of New York City, New York City banks, and savings and loan holding companies. The regressions also include the growth rate of real GNP to control for cyclical factors. The results are shown in table $5^{16}$

\footnotetext{
${ }^{14}$ All federally insured savings and loan associations are required by law to hold the bulk of their assets in the form of home mortgage loans with remaining maturities of nol less than eight years (Federal Home Loan Bank Act of 1932, sec. 2, p. 1). It was not until 1980 that federally insured institutions were allowed to invest up to 20 percent of their assets in shorter-term loans (Savings and loan Sourcebook 1982, p. 54).

${ }^{15}$ The first differences of the corporate Aaa bond rate can be characterized as representing unexpected changes in the interest rate. The hypothesis that the series represents white noise cannot be rejected. The Chi-square statistic based on 24 lags is 30.22 . In addition, three sets of initial regressions attempted to control for changes in the term structure of interest rates by including the percentage change in the three-month Treasury bill rate, the percentage change in the ratio of the three-month Treasury bill rate to the corporate Aaa bond rate and the percentage change in the difference between one plus the three-month Treasury bill rate and the corporate Aaa bond rate. However, these variables proved insignificant and were dropped from subsequent regressions.

${ }^{16}$ In the case of estimates 1,2 and 4 the procedure used was generalized-least-squares regression. Estimates 1 and 4 were
}

\section{Table 5}

\section{Estimates of Interest Rate Elasticity Sample Period: 11961-IV/1983}

\section{Estinate 1}

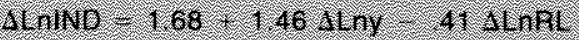

$$
\begin{aligned}
& (44)(2,57):(2 \times 8) \\
& \text { hso }=10 \\
& \text { 1610 } 1 \text { : }=\text { : } 2: 26 \\
& (256)
\end{aligned}
$$

\section{Estinate 2}

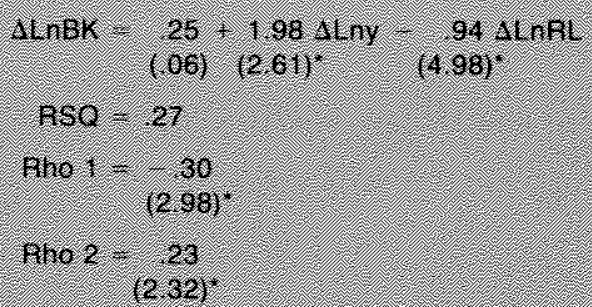

\section{tsilnate 8 .}

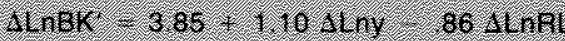

$$
\begin{aligned}
& \text { (9.1) }(1.39) \text { : } 2 \text { : (4.63): } \\
& \text { R50. } 19 \\
& \text { tow }=1.67
\end{aligned}
$$

\section{Esintate 4 .}

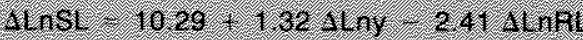

$$
\begin{aligned}
& (107)^{2} \cdot(9)=(6.7)
\end{aligned}
$$

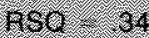

$$
\begin{aligned}
& \text { tho } 4.20 .020 \\
& (294)
\end{aligned}
$$

Where?

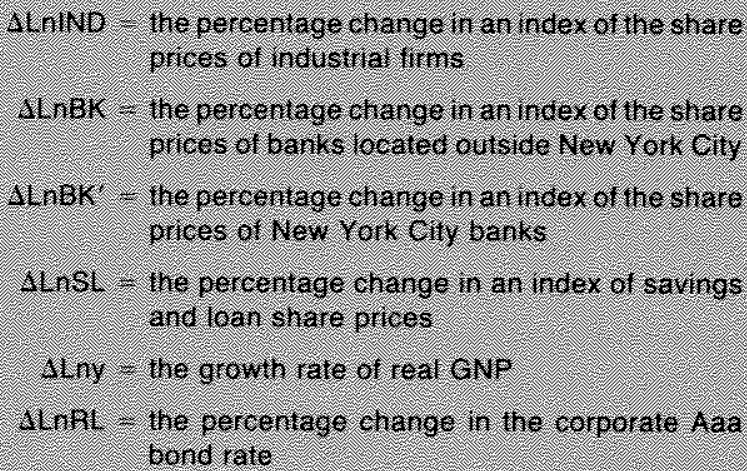

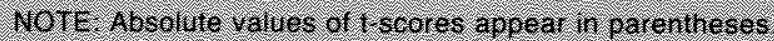
sugnilcarly viflerent fon zero at the 5 percent evel.

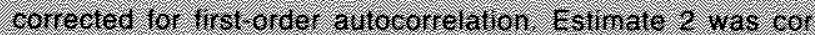

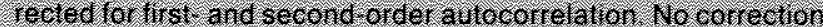
Vias required tor estimale 3 
In each of the regressions reported, the estimated coefficient of the percentage change in the long-term interest rate (corporate Aaa bond rate) - which is an estimate of the interest elasticity of the stock prices of the firms - is both negative and statistically significant. Increases in the long-term interest rate are associated with reductions in the capital values of both industrial and financial firms

The estimated coefficient of the growth rate in real GNP (the proxy for cyclical factors) is positive in each estimate. The positive sign of the coefficient indicates that expansions in economic activity are associated with increases in the stock prices of both industrial and financial firms. The coefficient is statistically significant, however, only in estimates 1 and 2 .

\section{Differential Interest Rate Elasticities}

The results in table 5, as expected, show that a given percentage change in the long-term interest rate produces differential effects on the share prices of the different types of firms. For example, a 1 percent increase in the long-term interest rate is associated with an average reduction of 0.4 percent in the net present value of industrial firms, a 0.9 percent reduction in the net present value of banks, and a 2.41 percent reduc tion in the net present value of savings and loan associations.

Since the coefficients of the percentage change in the long term interest rate are estimates of interest rate elasticity, the results indicate that, on average, the stock prices of savings and loans are about two and a half times more sensitive to changes in the long-term interest rate than are the stock prices of banks, and about five times more sensitive to such changes than are the stock prices of industrial firms. These differ ences are statistically significant. ${ }^{i}$

The relative ranking of the various types of firms indicated by these estimates of interest elasticity is consistent with that suggested by the previous discussion: financial firms are more highly levered than other firms, and savings and loans maintain asset/liability portfolios that are heavily weighted by long-term assets and short-term liabilities.

\footnotetext{
${ }^{17}$ When the ratio of the index of the prices of bank stock to the index of the prices of industrial stock was regressed on the same set of right-side variables as appear in table 5 , the coefficient of the long-lerm interest rate was negative and statistically signifcant for both of the proxies for the price of bank stock. The test was repeated using the ratio of the indexes of the prices of savings and loan stock to the prices of bank stock with the same results. In sum, unexpected increases in the long-term interest rate cause the stock prices of savings and loan associations to decline relative to the stock prices of banks, which decline relative to the stock prices of industrial firms.
}

\section{CONCLUSIONS}

The share prices of financial institutions land the wealth of their owners) are more sensitive to interest rate changes than are the share prices of industrial firms. This is true because financial institutions are highly levered relative to other firms and because the portfolios of savings and loan associations are composed of relatively long-term financial assets and relatively short-term fnancial liabilities. Because the market value of these institutions is particularly sensitive to changes in the long-term interest rate, financial firms (particularly savings and loan associations) are subject to greater interest rate risk.

Simply matching asset and liability durations will not insulate the firm against interest rate risk, In fact, complete insulation is probably undesirable. Interest risk can only be eliminated if these firms were to bor row long and lend short, that is, if they were to completely reverse their traditional practices. However, structuring portfolios in this way can be costly to financial institutions if, as suggested here, it reduces the credibility of the commitments these institutions make to depositors.

\section{REFERENCES}

Alchian, Armen A. "The Rate of Interest, Fisher's Rate Over Cost and Keynes' Internal Rate of Return," American Economic Review (December 1955), pp. 938-43.

Bierwag, G. O., George G. Kaufman, and Alden Toevs. "Duration: Its Development and Use in Bond Portfolio Management," Financial Analysts Joumal (July/August 1983), pp. 15-35.

Federal Home Loan Bank Act of 1932. Public No. 304, 72 Cong., HR 12280.

Flannery, Mark J. "Market Interest Rates and Commercial Bank Profitability: An Empirical Investigation," The Journal of Finance (December 1981), pp. 1085 102 .

Hicks, J. R. Value and Capital (Oxford: Clarendon Press, 1939).

Hopewell, Michael H., and George G. Kaufman. "Bond Price Volatility and Term to Maturity: A Generalized Respecification," American Economic Review (September 1973), pp. 749-53.

Kaufman, George G. "Measuning and Managing Interes! Rate Risk: A Primer," Federal Reserve Bank of Chicago Economic Perspectives (January/February 1984), pp. 16-29.

Maisel, Sherman J., and Robert Jacobson. "Interest Rate Changes and Commercial Bank Revenues and Costs," Journal of Financial and Quantitative Analysis (November 1978), pp. $687-700$.

Salomon Brothers, Inc. A Review of Bank Performance (1983), p. 54

Samuelson, Paul A. "The Effect of Interest Rate Increases on the Banking System" American Economic Review (March 1945), pp. 16-27.

Savings and Loan Sourcebook. (United States League of Sav. ings Associations, 1982.) 